WellBeing International

WBI Studies Repository

1984

\title{
Stereotype Behaviour in Sows and Gilts Housed in Stalls, Tethers, and Groups
}

Judith K. Blackshaw

University of Queensland

J. F. McVeigh

University of Queensland

Follow this and additional works at: https://www.wellbeingintlstudiesrepository.org/acwp_faafp

Part of the Agribusiness Commons, Animal Studies Commons, and the Operations and Supply Chain Management Commons

\section{Recommended Citation}

Blackshaw, J.K., \& McVeigh, J.F. (1984). Stereotype behavior in sows and gilts housed in stalls, tethers, and groups. In M.W. Fox \& L.D. Mickley (Eds.), Advances in animal welfare science 1984/85 (pp. 163-174). Washington, DC: The Humane Society of the United States.

This material is brought to you for free and open access by WellBeing International. It has been accepted for inclusion by an authorized administrator of the WBI Studies Repository. For more information, please contact wbisr-info@wellbeingintl.org.

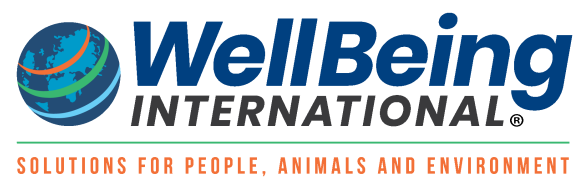




\title{
STEREOTYPE BEHAVIOUR IN SOWS AND GILTS HOUSED IN STALLS, TETHERS, AND GROUPS
}

\author{
Judith K. Blackshaw* and J.F. McVeigh** \\ *Department of Animal Production \\ University of Queensland, \\ St. Lucia, Queensland, 4067 \\ (Australia) \\ **Piggery Manager, Veterinary Science Farm \\ University of Queensland \\ Moggill Road \\ Pinjarra Hills, Queensland, 4069 \\ (Australia)
}

\section{ABSTRACT}

Observations of sows and gilts in tethers, stalls, and groups showed two distinct types of behaviour: pre-feed behaviour when pigs were anticipating food, and after-feed behaviour. Sows and gilts tethered for the first time do not show pre-feed excitement, but this develops in 42 days which suggests that pre-feed behaviour is not stereotype, as suggested by the literature, but is a conditioned reflex.

The question of the importance of after-feeding behaviours which are often called stereotypies is examined. The total time occupied by these behaviours over 24 hours by tethered sows is 14.5 to $29.0 \%$, by tethered gilts 1.4 to $5.6 \%$, by stalled sows 10 to $14 \%$, and 4.2 to $6.3 \%$ in stalled gilts.

Grouped animals do not show the same behaviours as the stalled and tethered ones.

Several examples of true stereotypies are described, but not all tethered or stalled pigs exhibit chronic bar biting. Changes in the en- 
vironment of two of these sows did not alter the fixed stereotype behaviour. Each individual seems to have an optimum level of environmental stimulation which may account for the great differences in individual behaviours.

\section{INTRODUCTION}

Those movements which are combined into rhythmic or complex sequences of obscure purpose are described as stereotypies. Hediger (1955) described stereotypies in caged zoo animals which included weaving to and fro, pacing up and down, and circling.

Removal of the animal from the cage may cause the stereotypy to cease, but this is not always so (Meyer-Holzapfel 1968). Novel objects may initially reduce the performance of stereotypies in horses but this lasts only as long as the object remains novel. In cases where animals have been performing the stereotypies for some time the introduction of a novel object may actually increase the frequency of the stereotypy (Kiley-Worthington 1983).

Some stereotypies may function as an adaptive mechanism and be regarded as the attempt of a normal individual to cope with an abnormal environment (Ridley and Baker 1982). This abnormal environment may result from conflict or frustration situations, low sensory input (boredom state) or very high sensory input (e.g. novel objects).

All these types of situations may contribute at some time to stereotypies reported in farm animals, such as bar-biting in tether stalled pigs (Fraser 1975) and weaving, wind-sucking, and crib-biting in horses (Kiley-Worthington 1983).

Some stereotypies in pigs and horses are performed when food is anticipated (Fraser 1975; Kiley-Worthington 1983). It has been suggested also that rapidly consumed food and the lack of even, lowquality, high fibre food to eat at leisure is a major cause of stereotypies in herbivores (Kiley-Worthington 1983).

Dantzer and Morméde (1981) suggested that pituitary-adrenal activity is a good indicator of emotional arousal. They looked at a chain-pulling stereotypy performed by food deprived pigs who were then submitted to an intermittent food delivery schedule (Dantzer et al. 1980; Dantzer and Morméde 1983). This chain-pulling activity was accompanied by decreased pituitary-adrenal activity which indicates a decrease in tension or anxiety. Their data suggests that stereotypies enable the animals to decrease excessive arousal, rather than provide an extra source of stimulation.

Horse stereotypies show many characteristics of learned behaviour (Kiley-Worthington 1983) which may be evoked by some mild 
stimulus (head tossing as a result of nasal irritation initially) or learning by imitation, as in some cases of crib-biting.

There is no published evidence for this in pigs but this study suggests there is an element of learning involved in the development of stereotypies. It also examines the behaviour performed by tethered, stalled, and groups of pigs before feeding and after feeding, and comments on the effect of changing the environment on several complex sequences of stereotypic behaviour in sows. Comment is also made on the notable absence of chronic bar-biting in this herd.

\section{MATERIALS AND METHODS}

The study was carried out in a 55-sow, specific pathogen-free herd at the Veterinary Science Farm Piggery, University of Queensland (Australia), during 1982-83. The behaviour of the animals (Large White $\mathbf{x}$ Landrace) in three husbandry systems for sows and gilts was examined.

(i) Stall system providing $1.04 \mathrm{~m}^{2} / \mathrm{pig}$;

(ii) Neck tether system providing $1.04 \mathrm{~m}^{2} / \mathrm{pig}$; but the $65 \mathrm{~cm}$ chain allows each pig to use $3.0 \mathrm{~m}^{2}$ of space effectively;

(iii) Group system of six pigs in a pen $\left(6.24 \mathrm{~m}^{2}\right)$.

Flooring was concrete in the stalls, each pig being provided with a concrete trough, concrete floor and slats with a metal trough in the tethers, and concrete floor and slats in the group pens with floor feeding.

Food was provided twice/day at 0800 to 0830 and 1300 to 1350 in the form of pellets.

\section{OBSERVATIONS-EXPERIMENT 1}

Two types of observations were made in each husbandry system:

(i) Detailed observations each week on 36 tethered sows, 8 tethered gilts, 9 sows in stalls, 10 gilts in stalls, two groups of 6 gilts, and five groups of 6 sows each, penned.

These observations were made from the time of confirmation of pregnancy when the pigs were put in the husbandry system until farrowing. Detailed observations were made on day 1 and covered the two feeding periods. Subsequent observations were done each week and covered only one feeding period. Behaviour was recorded from the time the pigs anticipated their food (5 to 15 minutes), during the feeding period and until the pigs lay down.

(ii) Surveys of all the pigs in stalls, tethers, and pens with time sampling during both the day and night. 


\section{EXPERIMENT 2}

Another section of the experiment was to determine how stereotypies develop. The two groups of penned gilts ( 6 in each group) from the previous experiment were used after farrowing as parity 1 sows and placed in tethers when pregnancy was confirmed. They were observed each week before, during and after a feed period to determine when or if, stereotypies developed.

\section{RESULTS}

\section{EXPERIMENT 1}

There were two distinct types of behaviour in stalled, tethered, and penned pigs:

(i) Before-feed behaviour, and

(ii) After-feed behaviour.

\section{PENNED SOWS AND GILTS}

The grouped sows (five groups of 6 sows) were only kept together for one day over two feeding periods, as the agonistic behaviour (conflict behaviour involving threats, bites, fights) prevented any other behaviour patterns from emerging.

The grouped gilts (two groups of 6 gilts) showed some pre-feed excitement which consisted of crowding and pushing to the fence as the food trolley came past. There was no pawing or head waving nor was there opportunity for any bar-biting. Agonistic activity which occurred over the first 16-minute feed period averaged 4 agonistic incidents/minute. This decreased over the next three months to average $1.8 /$ minute.

Pigs showed no true stereotypies after feeding - the first gilt lay down within 17-34 minutes after the beginning of feeding and all gilts were consistently lying by 76 minutes after feeding. There were examples of gilts who sat and chewed for up to 20 minutes in the afterfeed period, but this ceased when they lay down.

\section{STALLS AND TETHERS}

\section{Pre-feed behaviour}

Pre-feed excitement was shown in stalled sows and gilts, and in tethered sows and gilts when food was anticipated. These behaviours 
are similar to those described by Fraser (1975), and are listed in Table 1a. Day 1 is the day that the pig is put in the husbandry system and the frequency of the behaviour is noted over the first feeding period. The tethered and stalled sows showed more pre-feed behaviour sequences than the tethered and stalled gilts. Agonistic displays were not evident in tethered gilts, nor in stalled sows or gilts. The agonistic activities in the tethered sows dropped from $47 \%$ of all sows over the first two weeks to one example over the three-month period.

Table 1a. Pre-feed behaviours (5 to 12 minutes before feeding) and the frequency they occurred on the first day that sows and gilts are stalled or tethered.

\begin{tabular}{|c|c|c|c|c|c|c|c|}
\hline \multicolumn{4}{|c|}{ Tether } & \multicolumn{4}{|c|}{ Stalls } \\
\hline Sows $(36)$ & & Gilts (8) & & Sows (9) & & Gilts (10) & \\
\hline \multicolumn{8}{|l|}{ Day 1} \\
\hline $\begin{array}{l}\text { Agonistic } \\
\text { displays }\end{array}$ & $17^{*}$ & $\begin{array}{l}\text { Stand for } \\
\text { feed }\end{array}$ & 5 & $\begin{array}{l}\text { Yell } \\
\text { Paw }\end{array}$ & 7 & $\begin{array}{l}\text { Stand for } \\
\text { feed }\end{array}$ & 6 \\
\hline Yell & 26 & $\begin{array}{l}\text { Lie until } \\
\text { feed comes }\end{array}$ & 4 & Nosing bars & 2 & Paw & 1 \\
\hline Paw & 23 & Pull at & & Froth and & & $\begin{array}{l}\text { Stand and } \\
\text { chew }\end{array}$ & 1 \\
\hline Nosing bars & 10 & tether & 1 & chew bar & 4 & Chew bar & 1 \\
\hline $\begin{array}{l}\text { Froth and } \\
\text { chew bar }\end{array}$ & 12 & & & $\begin{array}{l}\text { Stand and } \\
\text { chew }\end{array}$ & 1 & $\begin{array}{l}\text { Poke nose in } \\
\text { and out front }\end{array}$ & \\
\hline $\begin{array}{l}\text { Stand and } \\
\text { chew }\end{array}$ & 1 & & & Wave head & 7 & bar & 1 \\
\hline Stand & 6 & & & $\begin{array}{l}\text { Poke nose in } \\
\text { and out front } \\
\text { bar }\end{array}$ & 6 & & \\
\hline Wave head & 18 & & & & & & \\
\hline
\end{tabular}

*frequency of behaviour

A pig may show more than one behaviour.

It can be seen (Table $1 \mathrm{~b}$ ) that some of the tethered gilts learned to chew the bar, wave their heads, paw and yell during the succeeding three-month observation period. However, there were 5 gilts who did not show these behaviours and stood up when food was anticipated.

Bar-biting was observed in 17 tethered sows consistently but was interspersed with pawing, yelling and head waving. Some stalled sows 
Table 1b. Pre-feed behaviours observed in tethered and stalled sows and gilts over a three-month period.

$\begin{array}{llll}\begin{array}{l}\text { Agonistic Displays } \\ \text { Yell }\end{array} & \text { Stand for feed } & \text { Yell } & \\ \text { Paw } & \text { Yell } & \text { Paw } & \text { Stand for feed } \\ \text { Nose bars } & \text { Paw } & \text { Nose bars } & \text { Stand and chew } \\ \begin{array}{l}\text { Froth and chew } \\ \text { bar }\end{array} & \text { Nose bar } & \begin{array}{c}\text { Froth and chew } \\ \text { bar }\end{array} & \text { Chew bar } \\ \begin{array}{l}\text { Stand and chew } \\ \text { Wave head }\end{array} & \text { Chew bar } & \begin{array}{c}\text { Poke nose } \\ \text { in and out of } \\ \text { front bar }\end{array} & \begin{array}{c}\text { Poke nose in } \\ \text { and out of } \\ \text { front bar }\end{array}\end{array}$

and gilts also bit the bar, but again it was interspersed with other activities.

These behaviours occupied a very small time period over 24 hours. It was 1.7 to $2.0 \%$ of the time in stalled and tethered sows, 0 to $0.4 \%$ in tethered gilts and 0 to $0.2 \%$ in stalled gilts.

Fraser (1975) refers to head waving as a stereotype but it is evident that none of these behaviours are stereotypies when the definition is considered. They are sequences which occur, and indeed might be expected, in animals who are waiting for their hunger to be satisfied.

\section{AFTER-FEED BEHAVIOUR}

This is one of the periods when stereotypies are reported to occur in pigs. The behaviours for stalled sows and gilts and tethered sows and gilts until they rest are shown in Table 2. These behaviours occupy between 14.5 to $29.0 \%$ of a 24 -hour period in tethered sows, 10.0 to $14.0 \%$ in stalled sows, 1.4 to $5.6 \%$ in tethered gilts and 4.2 to $6.3 \%$ in stalled gilts.

There were no examples of chronic bar-biting or the pre-feed behaviours of yell, paw, wave head, but there were several examples of true stereotypies which were performed continuously by individual 
Table 2. After-feed behaviours observed in tethered and stalled sows and gilts before rest.

\begin{tabular}{|c|c|c|c|}
\hline \multicolumn{2}{|c|}{ Tether } & \multicolumn{2}{|c|}{ Stalls } \\
\hline Sows (36) & Gilts (8) & Sows (9) & Gilts (10) \\
\hline Lie & Lie & Lie & Lie \\
\hline Lie and chew & Lie and chew & Lie and chew & Lie and chew \\
\hline Lick trough & Lick trough & Stand and chew & Stand and chew \\
\hline Stand and chew & Stand and chew & Lick trough & Sit and chew \\
\hline Chew trough & Rub nose on floor & $\begin{array}{l}\text { Rub nose on } \\
\text { trough }\end{array}$ & Sit \\
\hline Play with chain & & $\begin{array}{l}\text { Rub nose on } \\
\text { floor }\end{array}$ & Lick trough \\
\hline \multicolumn{4}{|l|}{ Rub nose on floor } \\
\hline Rub nose on trough & & & \\
\hline
\end{tabular}

pigs until they lay down. These were observed for three months:

(i) A tethered sow who continually pressed the water nozzle and squirted water over the floor in random bursts (45 seconds to 140 seconds with 3- to 5- second stops in between).

(ii) A tethered sow who sat poking her tongue in and out.

(iii) A tethered sow who pushed the water nozzle and licked the water in sequences of 27-30 seconds of continuous pressing, then a rest period of 2 seconds. This was repeated for an average of 165 minutes until the pig lay down.

(iv) A stalled sow who rubbed her nose in an upward direction on the two front bars of her stall in a random pattern which also had a random time component.

Kiley-Worthington (1983) points out that in horses there appears to be an optimum level of environmental stimulation for each individual. This seems to be similar to pigs and may account for the great differences in individual behaviours.

An interesting observation was that when the tethered pig who continually squirted water had farrowed and was placed in stalls she continued this stereotypy. Also the bar rubbing stereotypy described 
in the stalled sow continued when she was tethered. This indicated that a fixed stereotypy is difficult to stop even by a change of environment.

The frequencies of the other after-feed behaviours are given in the survey results for tethered pigs (Table 3) and stalled pigs (Table 4) which were done in the daytime. A survey of tethered and stalled pigs over 15 hours $(1500-0645)$ is shown in Tables $5 a$ and $5 b$.

One hour after feeding, stand and chew, followed by stand and lick trough, were the most common behaviours. Stand and chew was the most common behaviour for two to three hours following feeding, after which most pigs were resting.

Table 3. Behaviour of 30 tethered pigs on three different days (number indicates the number of pigs performing the behaviour).

\begin{tabular}{|c|c|c|c|c|c|}
\hline \multirow[b]{2}{*}{ Behaviour } & \multicolumn{2}{|c|}{ Day 1} & \multirow{2}{*}{$\begin{array}{c}\text { Day } 2 \\
\begin{array}{c}\text { hr } 40 \mathrm{~min} \\
\text { after feed } \\
(1240)\end{array}\end{array}$} & \multicolumn{2}{|c|}{ Day 3} \\
\hline & $\begin{array}{c}1 \mathrm{hr} \\
\text { before feed } \\
(0800)\end{array}$ & $\begin{array}{c}5-15 \mathrm{~min} \\
\text { before feed } \\
(0845)\end{array}$ & & $\begin{array}{c}1 \mathrm{hr} \\
\text { after feed } \\
(1500)\end{array}$ & $\begin{array}{c}3 \mathrm{hr} \\
\text { after feed } \\
(1700)\end{array}$ \\
\hline Lie only & 8 & 0 & 8 & 4 & 7 \\
\hline Lie and chew & 2 & 0 & 6 & 3 & 4 \\
\hline Stand only & 3 & 6 & 3 & 0 & 0 \\
\hline Stand and chew & 8 & 5 & 3 & 9 & 7 \\
\hline Stand and lick trough & 3 & 2 & 3 & 9 & 4 \\
\hline Sit only & 2 & 1 & 2 & 2 & 0 \\
\hline Sit and chew & 0 & 0 & 3 & 2 & 6 \\
\hline $\begin{array}{l}\text { Stand and poke } \\
\text { tongue in and out }\end{array}$ & 1 & 1 & 1 & 1 & 1 \\
\hline $\begin{array}{l}\text { Stand with nose } \\
\text { pressed on bar }\end{array}$ & 1 & & 0 & 0 & 0 \\
\hline Chew bar & 1 & & 0 & 0 & 0 \\
\hline Stand and head wave & 1 & 2 & 0 & 0 & 0 \\
\hline Stand, wave and paw & 0 & 6 & 0 & 0 & 0 \\
\hline $\begin{array}{l}\text { Stand, wave, } \\
\text { chew bar }\end{array}$ & 0 & 3 & 0 & 0 & 0 \\
\hline Stand and paw & 0 & 4 & 0 & 0 & 0 \\
\hline Play with chain & 0 & 0 & 0 & 0 & 1 \\
\hline
\end{tabular}


Table 4. The behaviour of 18 stalled pigs on day 1 , and 15 stalled pigs on day 2 (number indicates the number of pigs performing the behaviour).

\begin{tabular}{|c|c|c|c|c|c|c|}
\hline \multirow[b]{2}{*}{ Behaviour } & \multicolumn{3}{|c|}{ Day 1 (18 pigs) } & \multicolumn{3}{|c|}{ Day 2 (15 pigs) } \\
\hline & $\begin{array}{c}5-15 \mathrm{~min} \\
\text { before feed a } \\
(0845)\end{array}$ & $\begin{array}{c}3 \mathrm{hr} \\
\text { after feed } \\
(1200)\end{array}$ & $\begin{array}{c}4 \mathrm{hr} \\
\text { after feed } \\
(1300)\end{array}$ & $\begin{array}{l}1 \mathrm{hr} \\
\text { after feed } \\
(1500)\end{array}$ & $\begin{array}{l}2 \mathrm{hr} \\
\text { after feed } \\
(1600)\end{array}$ & $\begin{array}{l}3 \mathrm{hr} \\
\text { after feed } \\
(1700)\end{array}$ \\
\hline Lie only & 0 & 13 & 9 & 1 & 1 & 14 \\
\hline Lie and chew & 0 & 0 & 0 & 0 & 0 & 0 \\
\hline Stand only & 5 & 0 & 0 & 2 & 0 & 1 \\
\hline Stand and chew & 0 & 5 & 6 & 9 & 11 & 0 \\
\hline Stand and lick trough & 0 & 0 & 0 & 3 & 2 & 0 \\
\hline Sit only & 0 & 0 & 2 & 0 & 0 & 0 \\
\hline Sit and chew & 0 & 0 & 0 & 0 & 0 & 0 \\
\hline $\begin{array}{l}\text { Stand and } \\
\text { poke tongue }\end{array}$ & 0 & 0 & 0 & 0 & 0 & 0 \\
\hline $\begin{array}{l}\text { Nose pressed } \\
\text { on bar }\end{array}$ & 0 & 0 & 1 & 0 & 0 & 0 \\
\hline Chew bar & 4 & 0 & 0 & 0 & 1 & 0 \\
\hline Stand head wave & 9 & 0 & 0 & 0 & 0 & 0 \\
\hline Stand and paw & 0 & 0 & 0 & 0 & 0 & 0 \\
\hline
\end{tabular}

Table 5a. Behaviours observed in 35 tethered pigs from 1500-0645 hours (15 hr 45 min); fed at 1430 and all pigs lie from 1830 to 0640.

\begin{tabular}{lrrrrrrrrr}
\hline Behaviour & 1500 & 1530 & 1600 & 1630 & 1700 & 1730 & 1800 & 1830 & $0645^{*}$ \\
\hline Lie & 3 & 11 & 4 & 16 & 24 & 23 & 33 & 35 & 25 \\
Lie and chew & 0 & 0 & 2 & 2 & 2 & 4 & 0 & 0 & 0 \\
Stand & 1 & 10 & 19 & 3 & 3 & 4 & 2 & 0 & 7 \\
Stand and chew & 1 & 6 & 5 & 0 & 0 & 0 & 0 & 0 & 0 \\
Stand and lick trough & 29 & 6 & 0 & 10 & 0 & 0 & 0 & 0 & 3 \\
Sit & 1 & 1 & 2 & 2 & 5 & 1 & 0 & 0 & 0 \\
Sit and chew & 0 & 1 & 3 & 2 & 1 & 3 & 0 & 0 & 0
\end{tabular}

*The husbandman arrived to feed the pigs. 
Table 5b. Behaviours observed in 11 stalled pigs from 1500-0645 hours; fed at 1430 , and all pigs rest from 1830 to 0640 .

\begin{tabular}{lccccccccc}
\hline Behaviour & 1500 & 1530 & 1600 & 1630 & 1700 & 1730 & 1800 & 1830 & $0645^{*}$ \\
\hline Lie & 5 & 8 & 5 & 8 & 9 & 9 & 5 & 11 & 6 \\
Lie and chew & 0 & 0 & 0 & 0 & 0 & 0 & 1 & 0 & 0 \\
Stand & 3 & 0 & 0 & 3 & 1 & 0 & 4 & 0 & 3 \\
Stand and chew & 1 & 1 & 0 & 0 & 0 & 0 & 0 & 0 & 0 \\
Stand and lick trough & 2 & 1 & 4 & 0 & 0 & 0 & 0 & 0 & 0 \\
Sit & 0 & 1 & 2 & 0 & 0 & 1 & 1 & 0 & 0 \\
Sit and chew & 0 & 0 & 0 & 0 & 1 & 1 & 0 & 0 & 2 \\
\hline
\end{tabular}

*The husbandman arrived to feed the pigs.

\section{EXPERIMENT 2}

During the first observations after the parity 1 sows settled into their tethers there was not the pre-feed excitement exhibited by the older sows. None of them pawed, waved their heads back and forth, or yelled. These sows had been penned together until parturition and this was their first experience in tethers.

The sows, by 42 days in tethers, were exhibiting some pre-feed excitement by salivating, waving heads, and pushing their snouts through the front bars of the tether-stall.

After-feed behaviour included rubbing snout along the floor under the trough, licking inside the trough and chewing. All sows were lying down by 100 minutes after feeding although there were great individual differences. One sow consistently showed no after-feed behaviour and lay down immediately.

As yet, true stereotype behaviours have not developed in these animals, which suggests that an element of learning is involved in their development.

\section{CONCLUSIONS}

Only four examples of true stereotype behaviour appeared which might indicate that these individuals have a different tolerance level to the other animals. Changes in environment did not alter the complex fixed stereotype behaviour in two sows. It is suggested that some stereotype behaviour is conditioned. 
The pre-feed excitement is not stereotype behaviour according to the definition, but is a conditioned reflex. Only a few tethered or stalled sows and gilts exhibited chronic bar-biting before or after feeding.

There remains the question of whether the after feeding behaviours observed in most animals are true stereotype behaviours, as described in the literature. It seems unlikely that most of them are harmful to the welfare of the animals in this piggery.

The piggery in this study has several factors which may account for the lack of serious stereotypies:

(i) many students go into the piggery and handle the animals during clinical procedures,

(ii) several ongoing research projects are carried out continuously,

(iii) the husbandman is interested in the pigs' welfare.

If stereotypies are due to boredom and lack of stimulation as has been suggested, the presence of people may prevent this.

\section{EDITORS' ADDENDUM}

\section{ANIMAL RIGHTS AND THE NON-THERAPEUTIC USE OF DRUGS}

The use of prostaglandins to induce farrowing in pigs (regardless of the stage of farrowing at which different sows might be) is an animal welfare and rights issue. (I am not opposed to valid veterinary use of prostaglandins to help us deal with the reproductive problems of pigs, horses, and other animals that might otherwise jeopardize their health and well-being.) But it is surely ethically questionable to use prostaglandins to make sows in different stages of labor give birth at the same time, irregardless of potentially harmful consequences. This is done so that expectant sows will give birth during working hours. While this is consonant with the economic "efficiencies" of the hog factory farm, it certainly is not in accord with the biology and psychology of the sow. Judith Blackshaw has clearly demonstrated, in her research on sows being given prostaglandins near to delivery, that such treatment intensifies instinctual impulses and needs, which can lead to what humanitarians intuit as frustration and distress. The use of antibiotics as feed additives for farm animals and of analgesic drugs to enable injured and lame horses to be raced, are other examples of the unethical and commercial, as distinct from veterinary, use of drugs in animals today, which should be questioned. 


\section{REFERENCES}

Dantzer, R. and Mormede, P. 1981. Can physiological criteria be used to assess welfare in pigs? Curr. Topics Vet. Med. Anim. Sci. 11:53-73.

Dantzer, R. and Mormede, P. 1983. De-arousal properties of stereotyped behaviour: evidence from pituitary-adrenal correlates in pigs. Appl. Anim. Etho. 10:233-44.

Dantzer, R., Arnone, M. and Morméde, P. 1980. Effects of frustration on behaviour and plasma corticosteroid levels in pigs. Physiol. Beha. 24(1):1-4.

Fraser, D. 1975. The effect of straw on the behaviour of sows in tether stalls. Anim. Prod. 21:59-68.

Hediger, H. 1955. Studies of the psychology and behaviour of captive animals in zoos and circuses. New York:Criterion Press.

Kiley-Worthington, M. 1983. Stereotypes in horses. Equine Practice 5:34-40.

Meyer-Holzapfel, M. 1968. Abnormal behaviour in zoo animals. In: Fox, M.W. ed. $A b$ normal behaviour in animals. Philadelphia:W.B. Saundeson, pp. 476-503.

Ridley, R.M. and Baker, H.F. 1982. Stereotypy in monkeys and humans. Psychol. Med. 12:61-72. 